\title{
NOTES ON MYTILUS GALLOPROVINCIALIS LAMARCK IN GREAT BRITAIN
}

\author{
By B. T. HePper \\ Fisheries Experiment Station, Conway \\ (Plate I and Text-figs. I, 2)
}

Mytilus galloprovincialis Lmk., the 'Mediterranean' mussel, was first reported, as M. ungulatus L., from Britain by Donovan (1802), who recorded that several specimens were found in Cornwall (for details of synonymy see below). He noted that it was known at that time as a Mediterranean but not hitherto as a British species. Jeffrey (1863) also recorded $M$. ungulatus L. from Cornwall and the Channel Islands, probably referring to M. galloprovincialis Lmk. This author also included a M. galloprovincialis, but this was not the mussel referred to in the present paper.

M. edulis var. galloprovincialis was recorded from several places in Cornwall in 1866 by a correspondent to the Journal of the Royal Institution of Cornwall. Sowerby (1887) recorded $M$. edulis var. ungulata $\mathrm{L}$. from Cornwall and Guernsey and var. galloprovincialis from the English Channel. Tregellis (I896) recorded M. edulis var. galloprovincialis from Par, Falmouth, Helford and Hayle, and var. ungulata from Hayle and St Minver (all in Cornwall). Winckworth (1932) included the species in his list of British Marine Mollusca, but gave no locality. Dean recorded $M$. galloprovincialis as 'abundant in Cardiff Docks' (Conchological Soc., 1929), and Gardiner (1945) reported the species as present at Pendine, Carmarthenshire, and St Ives Bay and the Helford River, Cornwall.

In spite of these references to M. galloprovincialis in Britain, there seems to be no comprehensive account of the distribution of this species on our shores, or of its abundance relative to our common native mussel M. edulis $\mathrm{L}$., and the present paper attempts to remedy these deficiencies.

The lack of information about this species was brought to light in the course of work on the mussel parasite Mytilicola intestinalis Steuer, when it was noticed that although the copepod often established a high level of infection in Mytilus edulis in north-west Europe, and frequently caused heavy mortalities, such infestations were less frequently reported from the Mediterranean and no disastrous mortalities are recorded. Mytilicola has been present in the Mediterranean for over 50 years (Steuer, I902), but was not reported from north-west Europe until 1937 (Cole, 195I). These facts suggested that the Mediterranean mussel was in some way more resistant to the 
parasite than Mytilus edulis. If this were so, and if M. galloprovincialis would thrive in Britain, it might be of value for restocking mussel beds decimated by Mytilicola.

In 1952 Dr H. A. Cole drew my attention to a sample of mussels received from Padstow for bacteriological examination. These mussels differed in many respects from the normal Mytilus edulis of our shores. On examination it was found that $85 \%$ of the mussel population at Padstow was of the 'unusual' type of mussel, the remaining $15 \%$ being normal $M$. edulis. It was decided to investigate this 'Padstow-type' of mussel and to determine whether it was in fact M. galloprovincialis Lmk.

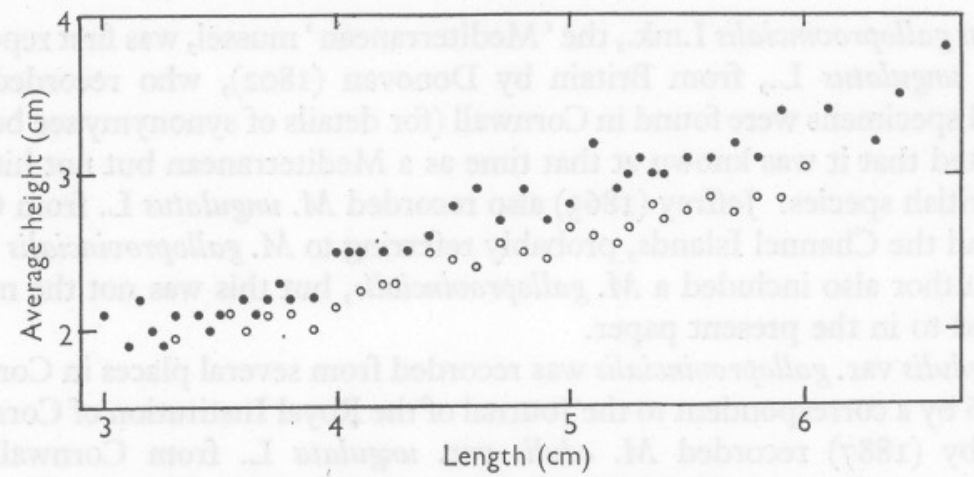

Text-fig. I. Comparison of mean values of height with length for Mytilus galloprovincialis (-) and M. edulis (O).

THE 'PADSTOW-TYPE' MUSSEL

The mussels from Padstow were found to differ from Mytilus edulis in the following respects. (I) The umbones were more pronounced, more pointed and down-turned (see Pl. I). (2) The shells were proportionately higher, the length/height ratio for $M$. edulis being $\mathrm{I} \cdot 95$ and $\mathrm{I} \cdot 77$ for the Padstow mussels (see Text-fig. I); these average figures were obtained from measurements of many specimens of each type. (3) The shells were less angular, and the distinct angle where the front and upper margins meet, which is often seen in M. edulis, was less evident, in the Padstow mussels (see P1. I). (4) They attained a larger size than $M$. edulis; individuals of $10-12 \mathrm{~cm}$ in length were quite common: in southern England M. edulis does not exceed 8-10 cm except under very favourable conditions. (5) The mantle edge was usually very dark, either blue, purple or violet, often appearing almost black, whereas in M. edulis it is much lighter, white to brown, usually appearing a straw colour.

EXPLANATION OF PLATE I

A. Mytilus galloprovincialis Lmk. from Padstow, Cornwall. Note the pronounced down-turned umbones, the high shells and the shape of the dorsal margin. B. M. edulis from Conway for comparison with A. 


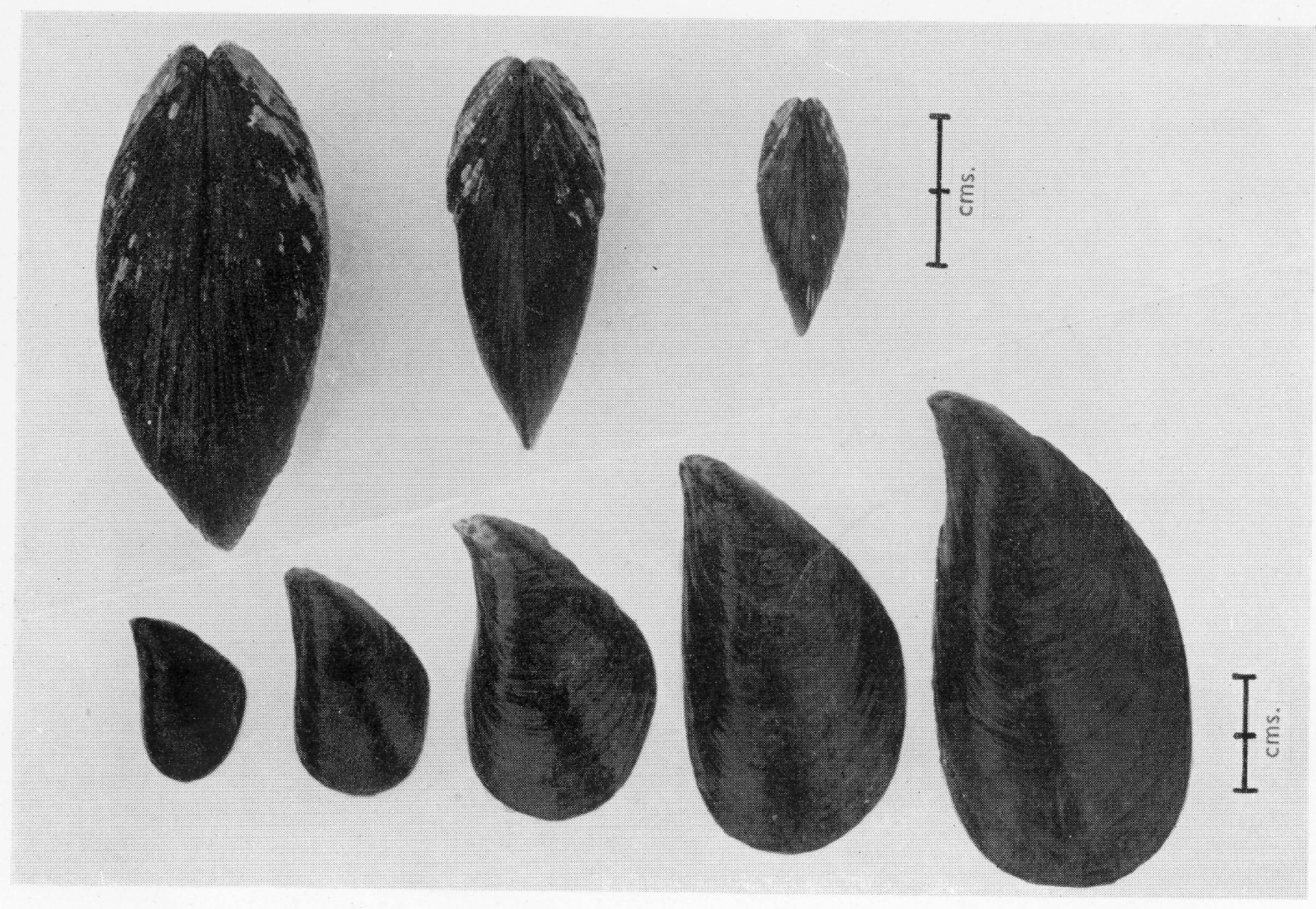

A

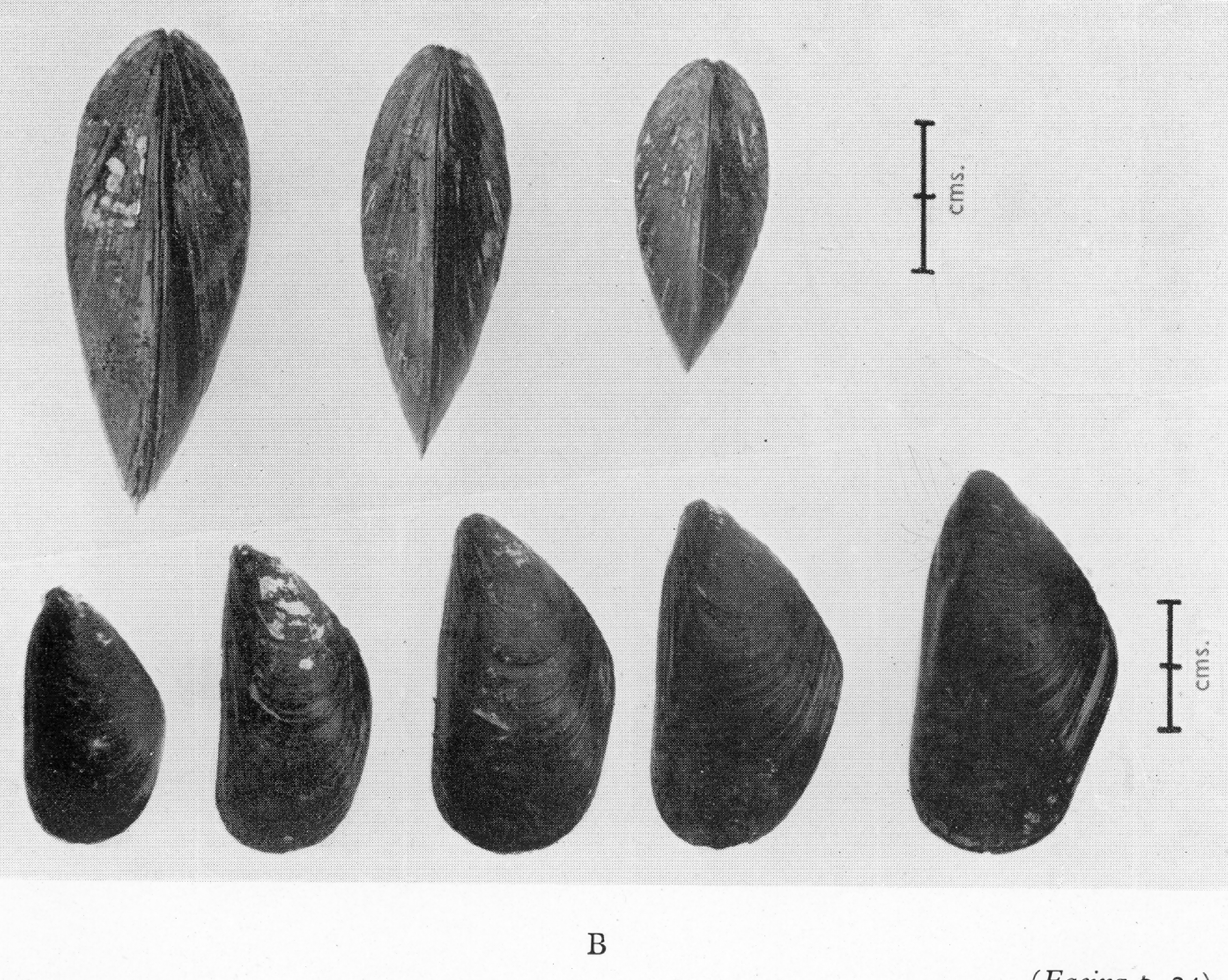


The literature on the Mytilidae appears to contain no detailed comparison of $M$. edulis and M. galloprovincialis, but the Padstow mussel seems to correspond to the description and figures of M. galloprovincialis given by List (I902) who describes the species in great detail. In both forms the umbones are pronounced and down-turned, the length/height ratio is very similar, being $\mathrm{I} \cdot 77$ for Padstow mussels and $\mathrm{I} \cdot 8$, calculated from List's measurements, for seventeen specimens of $M$. galloprovincialis, while the general shell outline of the Padstow mussel is similar to both the illustrations and descriptions given by List. The dark-coloured mantle edge of the Padstow mussel closely resembles that illustrated in colour by List for M. galloprovincialis.

Of other authors who have compared M. edulis and M. galloprovincialis, Sowerby (1887) states that M. edulis var. galloprovincialis is 'broader and flatter, beaks incurved', and gives an illustration of this mussel which is very similar in outline to the Padstow mussel, and appears larger than M. edulis. Forbes \& Hanley (I848), referring to the mantle edge of mussels, state '...usually in British specimens a yellowish white colour though sometimes...tinged with brown and in the foreign variety galloprovincialis they are deeply tinged with purple'. Lambert (I950), in a brief comparison of M. edulis and $M$. galloprovincialis, states ' . . the latter is larger, wider and its umbone is more pronounced'. Width in this context is taken to mean shell height.

Since the Padstow mussel corresponds so closely to the descriptions of M. galloprovincialis and also resembles closely specimens of this species in the Norman collection of the British Museum and comes from an area in which Mediterranean species are known to occur (Yonge, 1949), it must be concluded that it is in fact M. galloprovincialis Lmk.

\section{SYSTEMATICS}

In the earlier literature there appears to have been some confusion between M. ungulatus L. and M. galloprovincialis Lmk. Lamy (1920) states that the two are synonymous, and List (I902) appears to have been of the same opinion. However, it appears that M. ungulatus is a form of edulis, and in fact Linnaeus ( $175^{8}$, Ioth ed.) himself suggested this, and the figures to which he referred appear to be of distorted specimens of $M$. edulis. In the I2th edition of the Systema Naturae Linnaeus (1767) enlarged on his description of $M$. ungulatus given in the Ioth edition. Lamarck (1819) appears to have been fully aware of both Linnaeus's $M$. ungulatus and $M$. edulis when describing M. galloprovincialis. Dodge (1952) considers M. ungulatus to be a species of doubtful validity and this appears to be the opinion of most conchologists at the present time. In view of this confusion it seems probable that the $M$. ungulatus which Jeffrey (1863) recorded from the coasts of Cornwall and the Channel Islands was in fact M. galloprovincialis Lmk. Donovan (I802) recorded $M$. ungulatus from the coast of Cornwall and his colour illustrations 
of this species so closely resemble in all respects the $M$. galloprovincialis taken from Cornwall, that it must be concluded that he was referring to the lastnamed species.

\section{DISTRIBUTION}

To study the distribution of M. galloprovincialis in Britain, and to determine whether stocks of this species were available for restocking mussel beds decimated by Mytilicola, surveys were made along the south-west peninsula of England, and on the south coast of Wales. Mytilus galloprovincialis was known to be absent from North Wales and the south coast of England from Teignmouth eastwards. At each site visited a sample of mussels was collected covering a wide range of sizes. The number of mussels varied according to quantities available. The mussels in each sample were sorted into groups of $M$. edulis and M. galloprovincialis on the criteria given above, and the percentage of the latter was calculated.

Results are shown in Table I, and in Text-fig. 2 the proportion of M. galloprovincialis and its distribution are shown.

It will be noticed that the mussel populations of north-west Devon and north and south-west Cornwall are dominated by $M$. galloprovincialis, with occasional specimens of this species occurring on the south coast as far east as Plymouth. In South Wales $M$. galloprovincialis occurs in small numbers at many points along the coast, being most common at Cardiff where it forms about half of the mussel population.

The absence of this mussel from the inlets of the Carmarthen coast can be explained on the grounds that it intolerant of estuarine conditions (see below).

The well-defined zone of distribution of this mussel, with the rapid fall in the proportions of $M$. galloprovincialis over a short distance at the edges of the zone, suggests that this species would not be successful elsewhere in Britain. Although adult $M$. galloprovincialis have been kept in aquarium tanks at the laboratory at Burnham-on-Crouch in circulating River Crouch water for over a year, without any apparent ill effects, young specimens of $\mathrm{I}-2 \mathrm{~cm}$ in length died within a few days of being placed in the River Crouch.

Some mussels received from Castletownbere in Southern Eire, collected by my colleague, $\mathrm{Mr} \mathrm{R}$. H. Baird, were found to be $M$. galloprovincialis, but it has not been possible to make a detailed study of its ecology in that area.

M. galloprovincialis has been reported from Concarneau, Finistère, by Bouxin (1955). Sinel (1906) mentions a $M$. angulata, 'the hoof mussel', and since he worked largely in the Channel Isles it may be assumed that the mussel he mentions was found there, and that he was in fact referring to M. galloprovincialis, 'angulata' being a corruption of 'ungulatus'. 
TABLE 1. PERCENTAGE OF MYTILUS GALLOPROVINCIALIS

AT SITES SURVEYED

\begin{tabular}{|c|c|c|c|c|c|}
\hline Locality & $\begin{array}{l}\text { No. in } \\
\text { sample }\end{array}$ & $\begin{array}{c}\text { Mytilus } \\
\text { gallo- } \\
\text { provincialis } \\
(\%)\end{array}$ & Locality & $\begin{array}{l}\text { No. in } \\
\text { sample }\end{array}$ & $\begin{array}{l}\text { Mytilus } \\
\text { gallo- } \\
\text { provincialis } \\
(\%)\end{array}$ \\
\hline Angle Bay & 60 & 30 & Newlyn & 104 & 89 \\
\hline Tenby & I47 & I & Penzance & II 2 & 94 \\
\hline Pendine & 56 & 40 & Porthleven & 68 & 87 \\
\hline Mumbles & 72 & 13 & Helford R.* & II 3 & 32 \\
\hline Aberthaw & 45 & 26 & Falmouth & 260 & 75 \\
\hline Cardiff & $\begin{array}{l}43 \\
110\end{array}$ & 60 & Fowey & 100 & 20 \\
\hline Instow* & 20 & 35 & Plymouth & 200 & 2 \\
\hline $\begin{array}{l}\text { Appledore } \\
\text { Westward } \mathrm{Ho!}\end{array}$ & $\begin{array}{l}99 \\
58\end{array}$ & $\begin{array}{l}53 \\
88\end{array}$ & Estuari & e Fal & \\
\hline Padstow & 180 & 85 & Falmouth Harbour & ir 260 & 75 Marine \\
\hline Newquay & 89 & 88 & St Just & 40 & \\
\hline Gwithian & 145 & 95 & King Harry Reach & h 40 & Io \\
\hline Tav & 73 & 97 & Malpas & 40 & o Brackish \\
\hline
\end{tabular}

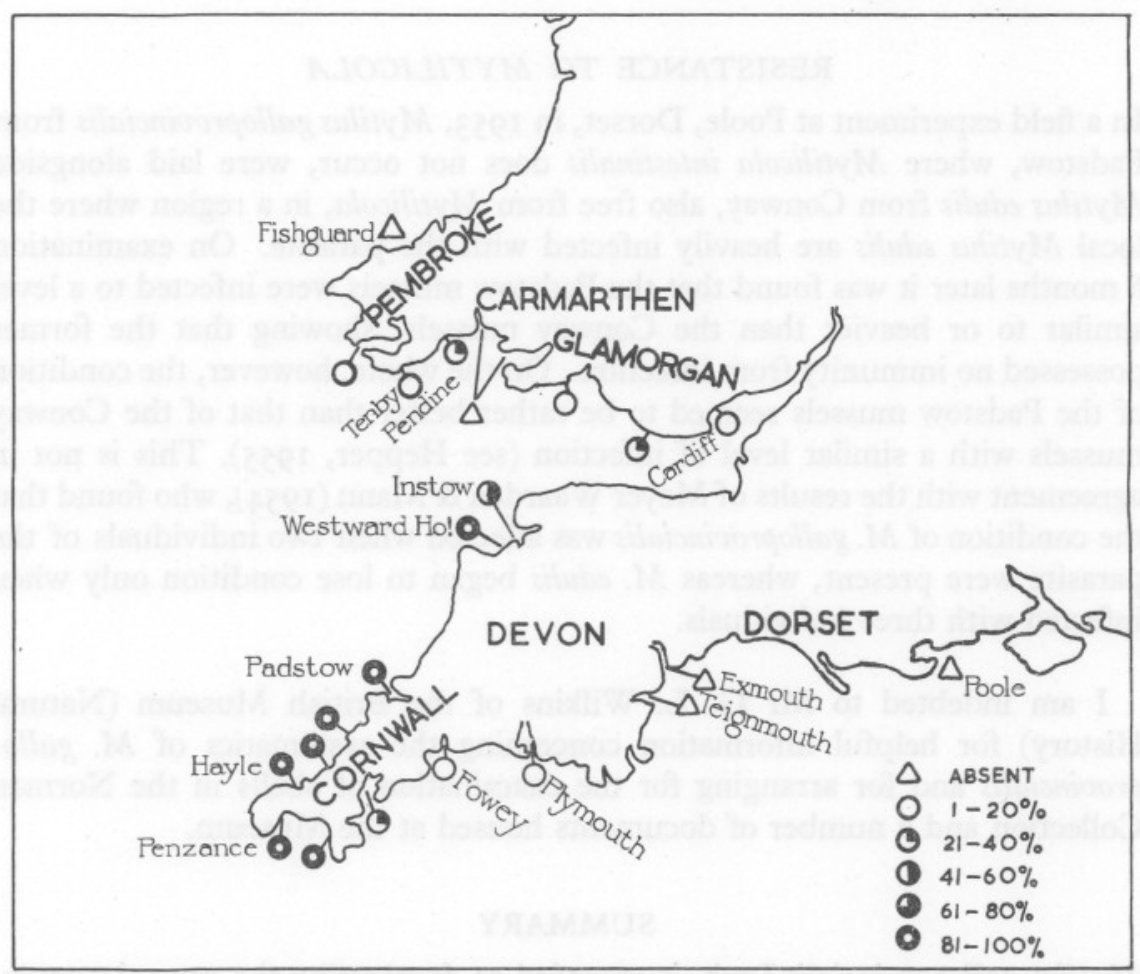

Text-fig. 2. Map of distribution of Mytilus galloprovincialis in Britain, showing the proportion of M. galloprovincialis in the mussel population. 


\section{ECOLOGY}

M. galloprovincialis appears to occur in all types of habitat where salinity is not greatly reduced. On rocks on open exposed shores the mussel is stunted and thick-shelled, but at all times the characteristic features are maintained. In less turbulent waters, as in harbours and inlets, the mussel occurs in dense beds or clusters and grows to a very large size.

In surveys in the $\mathrm{Fal}$ and Truro rivers, and at Looe, M. galloprovincialis was found predominantly at the mouth of the estuary, being gradually replaced by M. edulis farther upstream (Table I). A similar situation was observed in the Camel estuary, at Padstow, but there the proportion of M. edulis was so small, and so very few mussels occurred in the less saline regions, that it would perhaps be unwise to draw any conclusions from this observation. It was noticeable that the few M. galloprovincialis found at Fowey and Plymouth were taken from the lower regions of the estuaries.

On a suitable substratum $M$. galloprovincialis appears to cover about the same vertical range as $M$. edulis.

\section{RESISTANCE TO MYTILICOLA}

In a field experiment at Poole, Dorset, in 1953, Mytilus galloprovincialis from Padstow, where Mytilicola intestinalis does not occur, were laid alongside Mytilus edulis from Conway, also free from Mytilicola, in a region where the local Mytilus edulis are heavily infected with the parasite. On examination 6 months later it was found that the Padstow mussels were infected to a level similar to or heavier than the Conway mussels, showing that the former possessed no immunity from infection. On the whole, however, the condition of the Padstow mussels seemed to be rather better than that of the Conway mussels with a similar level of infection (see Hepper, 1955). This is not in agreement with the results of Meyer Waarden \& Mann (1954), who found that the condition of $M$. galloprovincialis was affected when two individuals of the parasite were present, whereas $M$. edulis began to lose condition only when infected with three individuals.

I am indebted to Mr G. L. Wilkins of the British Museum (Natural History) for helpful information concerning the systematics of M. galloprovincialis and for arranging for the examination of shells in the Norman Collection and a number of documents housed at the Museum.

\section{SUMMARY}

Mytilus galloprovincialis Lmk. is recorded as dominating the mussel population on the north coast of Devon and the north and south-west coasts of Cornwall from Instow to the Lizard. It was also found less frequently on the 
coast of South Wales from Angle to Cardiff and on the south coast of Cornwall from the Lizard to Plymouth.

The chief distinguishing features of $M$. galloprovincialis from Cornwall are summarized, in comparison with M. edulis L.

M. galloprovincialis is apparently intolerant of estuarine conditions, but otherwise appears to be ecologically similar to M. edulis.

M. galloprovincialis is not resistant to infection by Mytilicola intestinalis, but appears to be less affected by the parasite than is Mytilus edulis.

The synonymy of the species is briefly discussed and it is concluded that, although earlier workers tended to confuse $M$. ungulatus L. (recorded also as $M$. ungulata and M. angulata) with M. galloprovincialis Lmk., the two types are distinct. M. ungulatus is a name of doubtful validity applied by Linnaeus to a distorted form of $M$. edulis.

\section{REFERENCES}

ANoN., I866. Cornish marine shells. F. roy. Instn Cornwall, Vol. 2, pp. 65-72.

BouxIN, H., I955. Observations sur le frai de Mytilus edulis var. galloprovincialis (Lmk.) Rapp. Cons. Explor. Mer, Vol. 140, pp. 4I-4.

Cole, H. A., I951. Le Mytilicola en Angleterre. Rev. Trav. Off. Pêches marit., T. I7, Fasc. 2, pp. 59-6r.

Conchological Society, I929. Recorder's Report (Marine molluscs). F. Conch., Vol. 18, p. 300.

Dodge, H., I952. A historical review of the mollusks of Linnaeus. Pt. I. The class Loricata and Pelecypoda. Bull. Amer. Mus. nat. Hist., Vol. I00 (I).

Donovan, E., I802. The Natural History of British Shells. London: F. and C. Rivington.

Forbes E. \& Hanley, S. I848. A History of British Mollusca. London: John Van Voorst.

GARDINER, A. P., I945. British marine records. F. Conch., Vol. 22, p. I48.

HEPPER, B. T., I955. Environmental factors governing the infection of mussels, Mytilus edulis, by Mytilicola intestinalis. Fish. Invest. Lond., Ser. 2, Vol. 20, no. 3 .

JefFrey, J. G., I863. British Conchology. London: John Van Voorst.

Lamarck, J. B. M., I819. Histoire Naturelle des Animaux sans Vertèbres. Paris.

Lambert, L., 1950. Les Coquillages Comestibles. Paris: Presses Universitaires de France.

LAMY, E., I920. Notes sur les espèces de Mytilus décrites par Lamarck. Bull. Mus. Hist. nat. Paris, T. 26, pp. 520-6.

LinNaeus, C., I758. Systema Naturae. Ioth ed. Stockholm.

- 1767. Systema Naturae. I2th ed. Stockholm.

List, T., I902. Die Mytilieden des Golfes von Neapel. Fauna u. Flora Neapel, Monogr. 27, 312 pp.

MEYeR WAARDEN, P. F. \& MANN, H., I954. Untersuchungen über die Bestande von Mytilus galloprovincialis an der italienischen Küste auf ihren Befall mit Mytilicola intestinalis (Copepoda parasitica). Boll. Pesca Piscic. Idrobiol., Ann. 29, N.S. Vol. 8, Fasc. 2, pp. 5-24.

Sinel, J., I906. An Outline of the Natural History of our Shores. London: Swan Sonnenschein. 
Sowerby, G. B., I887. Illustrated Index of British Shells. London: Sowerby and Simpkin Marshall.

STEUER, A., 1902. Mytilicola intestinalis, n.gen. n.sp., aus dem darme von Mytilus galloprovincialis Lam. Zool. Anz., Bd. 25, p. 635.

Tregellis, J., I896. The marine Mollusca of Cornwall. f. Conch., Vol. 8, No. 6, pp. I9I-200, 209-25.

WincKWorth, R., I932. The British marine Mollusca. F. Conch., Vol. 19, pp. 2 I I-52. YoNGE, C. M., 1949. The Sea Shore. London: Collins, New Naturalist Series. 